\title{
Recent Developments on the Role of International Law in Canadian
} Statutory Interpretation

\author{
STÉPHANE BEAULAC*
}

In the case of Baker v. Canada (Minister of Citizenship and Immigration), ${ }^{1}$ in 1999 , the Supreme Court of Canada clearly expressed the view that the principles and values reflected in international conventional law, albeit not implemented into the domestic law of the country, should inform the contextual interpretation of Canadian legislation. This reasoning falls within the broader strategy in favour of taking into account international law in the interpretation of statutes and other instruments like the Canadian Charter of Rights and Freedoms. ${ }^{2}$ A similar approach was adopted by the majority of the Court in 114957 Canada Ltée (Spraytech, Société d'arrosage) v. Hudson (Town) ${ }^{3}$ and unanimously in Suresh v. Canada (Minister of Citizenship and Immigration). ${ }^{4}$

These decisions were construed as challenging the traditional Canadian position, based on the so-called dualist approach to international conventions, ${ }^{5}$ which requires that treaty norms be implemented through legislation

Assistant-Professor at the Faculty of Law, University of Montreal. The author wants to express his gratitude to his colleague Pierre-André Côté for his most useful comments on the piece. Thanks also to Suzanne Lalonde for her helpful suggestions on an earlier version of the text. [1999] 2 SCR 817 (hereinafter Baker).

2 Part I of the Constitution Act 1982, being Schedule B to the Canada Act 1982 (UK) 1982, c 11; RSC 1985 Appendix II, No 44 (hereinafter Charter).

[2001] 2 SCR 241 (hereinafter Hudson).

[2002]1 SCR 3 (hereinafter Suresh).

One must not confuse the domestic legal effect of treaties and that of customary international law; in Canada, the former is generally considered dualist and the latter is generally considered monist. According to the dualist theory, international law is only applicable domestically if there has been some kind of incorporation in the domestic legal order, the two systems being considered as separate. Pursuant to the monist theory, the rule is that 'international law forms part of the law of the land', without any need of internal implementation, a position based on the view that both laws are fundamentally part of the same legal system. Monism can take one of two forms: either that international law has primacy over domestic law or, the other way around, that municipal law trumps international law. The author Hans Kelsen is the most notorious defender of the monist theory, and he favoured the former form of monism; see Das Problem der Souveränität und die Theorie des Völkerrechts-Beitrag zu einer Reinen Rechtslehre, H. Kelsen (Tübingen: Mohr, 1920) at 102 et 
in order to have legal effect on domestic law. ${ }^{6}$ This rule of British origin was set out by the Judicial Committee of the Privy Council in the 1937 Labour Conventions case, ${ }^{7}$ where Lord Atkin famously wrote: 'Within the British Empire there is a well-established rule that the making of a treaty is an executive act, while the performance of its obligations, if they entail alteration of the existing domestic law, requires legislative action. ${ }^{\prime 9}$

seq.; and, H. Kelsen, 'La transformation du droit international en droit interne', 43 Rev Gén D Int'1 Pub 5 (1936). See also, generally, H. Triepel, Droit international et droit interne (Oxford: Oxford University Press, 1920) at 73 et seq.; H. Triepel, 'Les rapports entre le droit interne et le droit international', 1 Rec C Acad D Int'l 73 (1923); and, G. Sperduti, 'Dualism and Monism: A Confrontation to be Overcome?' 3 Italian YB Int'1 L 31 (1977). Finally, it is noteworthy that these dualist and monist theories are closely linked to the fundamental question of the sources and foundations of our legal order; see on this issue, L. Ferrari-Bravo, 'International and Municipal Law: The Complementary of Legal Systems', in R. St.J. Macdonald and D. M. Johnston (eds) The Structure and Process of International Law (Dordrecht: Martinus Nijhoff, 1983) at 715 .

6 See R. St.J. Macdonald, 'The Relationship Between International Law and Domestic Law in Canada', in R. St.J. Macdonald et al. (eds), Canadian Perspectives on International Law and Organization (Toronto: University of Toronto Press, 1974) at 88; A. Desjardins, 'La mise en oeuvre au Canada des traités relatifs aux droits de la personne', 12 Rev Générale D 359 (1981); I. Weiser, 'Effect in Domestic Law of International Human Rights Treaties Ratified without Implementing Legislation', 27 Canadian Council Int'1 L Proc 132 (1998); W. A. Schabas, 'Twenty-Five Years of Public International Law at the Supreme Court of Canada', 79 Canadian Bar Rev 174 (2000); S. J. Toope, 'Inside and Out: The Stories of International Law and Domestic Law', 50 UNB LJ 11 (2001); S. J. Toope, 'The Uses of Metaphor: International Law and the Supreme Court of Canada', 80 Can Bar Rev 534 (2001); B. Conforti, 'Notes on the Relationship between International Law and National Law', 3 Int'1 L Forum 18 (2001); and, H. Kindred, 'The Use of Unimplemented Treaties in Canada: Practice and Prospects in the Supreme Court', in S. G. Coughlan and D. Russell (eds), Citizenship and Citizen Participation in the Administration of Justice (Montreal: Thémis 2002) at 263.

7 Attorney General for Canada v. Attorney General for Ontario [1937] AC 326 (PC) (hereinafter Labour Conventions).

8 For comments on this case, see N. A. M. Mackenzie, 'Canada: The Treaty-Making Power', 18 British YB Int'l L 172 (1937); N. A. M. Mackenzie, 'Canada and the Treaty-Making Power', 15 Canadian Bar Rev 436 (1937); F. R. Scott, 'The Consequences of the Privy Council Decisions', 15 Canadian Bar Rev 485 (1937); A. B. Elkin, 'De la compétence du Canada pour conclure les traités internationaux-Étude sur le statut juridique des Dominions britanniques, 45 Rev gén D Int'l pub 658 (1938); F. R. Scott, 'Labour Conventions Case: Lord Wright's Undisclosed Dissent', 34 Canadian Bar Rev 114 (1956); G. J. Szablowski, 'Creation and Implementation of Treaties in Canada', 34 Canadian Bar Rev 28 (1956); E. McWhinney, 'Federal Constitutional Law and the Treaty-Making Power', 35 Canadian Bar Rev 842 (1957); E. McWhinney, 'The Constitutional Competence within Federal Systems as to International Agreements', 1 Canadian Leg St 145 (1964-68); G. L. Morris, 'The Treaty-Making Power: A Canadian Dilemma' 45 Canadian Bar Rev 478 (1967); E. McWhinney, 'Canadian Federalism: Foreign Affairs and Treaty Power. The Impact of Quebec's "Quiet Revolution"' 7 Canadian YB Int'l L 3 (1969); A. Dufour, 'Fédéralisme canadien et droit international', in R. St.J. Macdonald et al. (eds), Canadian Perspectives on International Law and Organization (Toronto: University of Toronto Press, 1974) at 72; A. M. Jacomy-Millette, 'L'État fédéré dans les relations internationales contemporaines: le cas du Canada', 14 Canadian YB Int'1 L 20 (1976); and, J.-Y. Morin, 'La personnalité internationale du Québec', 1 Rev québécoise D Int'1 163 (1984).

9 Labour Conventions at 347. 
Within the federal constitutional system of Canada, ${ }^{10}$ such legislative transformation of treaty obligations must be done by the legislative authority competent on the matter, under sections 91 and 92 of the Constitution Act 1867..$^{11}$

On 12 September 2002, the Supreme Court handed down its unanimous judgment in Schreiber v. Canada (Attorney General), ${ }^{12}$ which essentially raised a question of sovereign immunity; it is the State Immunity $\mathrm{Act}^{13}$ which implemented this principle of international customary law, as well as its exceptions, into the Canadian legal order. This case revolved around the interpretation of domestic statutory provisions, having regard to international law. More particularly, the Court had to decide whether the exceptions found in sections 4 and 6(a) of the Act, which limit the general principle of sovereign immunity in section 3(1), applied in the circumstances at hand. What is most interesting to consider is whether the reasons given by the Court signal a change of attitude vis-à-vis the use international law as a material contextual element in legislative interpretation.

The paper begins by briefly reviewing the facts of the Schreiber case, gives a succinct account of the judgment, and then focuses on the role of international law in the interpretation of statutes, and other instruments like the Charter in Canada.

\section{Schreiber: factual context}

The case is linked to a broader dispute about allegedly suspicious transactions for the purchase of aircraft involving the Canadian government when Prime Minister Brian Mulroney was in office in the 1990s. The appellant Schreiber was a business person and a Canadian citizen against whom the Federal Republic of Germany issued an arrest warrant in 1999. Under the Extradition Treaty between Canada and Germany, ${ }^{14}$ a request was then made for the provisional arrest of Schreiber and his extradition to face charges of tax evasion and other offences in Germany. The appellant was thus duly arrested

10 It is interesting to note that, unlike the situation in Australia, there is no distinct federal power to incorporate treaties in Canada. The Australian courts have indeed interpreted broadly the competence of the Commonwealth Parliament over 'external affairs' in order to include the authority to incorporate treaty obligations generally; see J. W. Perry, 'At the IntersectionAustralian and International Law', 71 Australian LJ 841 (1997); and S. Donaghue, 'Balancing Sovereignty and International Law: The Domestic Impact of International Law in Australia', 17 Adelaide L Rev 213 (1995).

11 (UK), 30 \& 31 Vict c 3 . See also Labour Conventions case, at 351, where Lord Atkin said: 'For the purposes of $[\ldots]$ the distribution of legislative powers between the Dominion and the Provinces, there is no such thing as treaty legislation as such. The distribution is based on classes of subjects; and as a treaty deals with a particular class of subjects so will the legislative power of performing it be ascertained.'

12 [2002] 2 SCR 269 (hereinafter Schreiber).

13 RSC 1985, c S-18 (hereinafter Act).

14 Can. TS 1979 No 18, entered into force on 30 September 1979. 
pursuant to a provisional arrest warrant granted under the Extradition $\mathrm{Act}^{15}$ and spent eight days in jail until he was released on bail.

Later the same year, Schreiber sued the respondents, Germany and the Attorney General of Canada, seeking one million dollars in damages for personal injuries resulting from his arrest and detention. His statement of claim alleged breaches of duties of care, abuse of public office, bad faith, and breach of his rights under the Charter. Germany brought a motion requesting that the action be dismissed on the basis of the principle of sovereign immunity. The Attorney General of Canada also brought a motion seeking a stay of proceedings pending the decision in the case between Schreiber and Germany. The Ontario Superior Court of Justice allowed both motions, ${ }^{16}$ a decision upheld by the Court of Appeal for Ontario. ${ }^{17}$ Only the issue of sovereign immunity was appealed to the Supreme Court of Canada.

\section{Schreiber: decision of the Court}

The only question before the Court, therefore, was whether or not the waiver of immunity exception in section 4 of the Act or the personal injury exception in section 6(a) of the Act applied, thereby depriving Germany of its sovereign immunity from judicial proceedings in Canada otherwise recognized under section 3(1) of the same Act. The answer given by the Court, unanimously, was negative and the appeal was dismissed.

Justice LeBel, who wrote the reasons for the Court, began by examining the international law origins and scope of the principle of sovereign immunity. ${ }^{18}$ He pointed out that the idea had developed from the Vattellian doctrine of the law of nations which regulated the Westphalian system of international relations based on the notion of sovereignty and equality of states, ${ }^{19}$ and was crystallized in the Charter of the United Nations. ${ }^{20}$ Sovereignty immunity, wrote LeBel J, would find justification in the old Latin maxim par in parem imperium non habet (an equal has no authority over an equal). This principle of international law was recognized and applied by states; domestic courts do not exercise jurisdiction in actions against foreign states (although they may act as plaintiffs in domestic courts as a matter of comity).

This general principle has been attenuated over the years and some exceptions to sovereign immunity have emerged. Evidence of developments

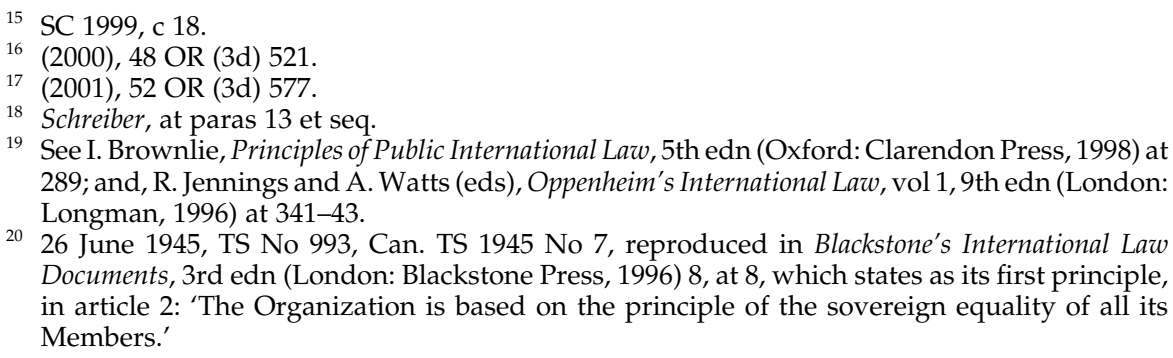

19 See I. Brownlie, Principles of Public International Law, 5th edn (Oxford: Clarendon Press, 1998) at 289; and, R. Jennings and A. Watts (eds), Oppenheim's International Law, vol 1, 9th edn (London: Longman, 1996) at 341-43.

2026 June 1945, TS No 993, Can. TS 1945 No 7, reproduced in Blackstone's International Law Documents, 3rd edn (London: Blackstone Press, 1996) 8, at 8, which states as its first principle, in article 2: 'The Organization is based on the principle of the sovereign equality of all its Members.' 
toward a more restrictive approach to immunity at international law can be found in the Council of Europe's European Convention on State Immunity ${ }^{21}$ and the International Law Commission's Draft Articles on Jurisdictional Immunities of States and their Property and Commentaries Thereto, ${ }^{22}$ as well as in the domestic legislation of several jurisdictions, including the USA, the UK, Australia, and Canada (which adopted the State Immunity Act). Justice LeBel insisted, however, that 'the general principle of sovereign immunity remains an important part of the international legal order, except when expressly stated otherwise' ${ }^{23}$

The Court then examined the two heads of exceptions under the Act that could here limit sovereign immunity. Under section 4, the waiver of immunity exception could not apply because Germany did not initiate the judicial proceedings on which the appellant based his torts liability action. Although Germany did initiate the extradition, this procedure is separate and distinct from the request to arrest and imprison Schreiber (the basis for his suit); actually, the request for extradition was made by the Minister of Justice who authorized the Attorney General of Canada to obtain a provisional warrant for his arrest. Furthermore, the review / appellate provision in section 4 of the Act was deemed irrelevant given that the present case did not fall within the waiver of immunity exception in the first place. Such conclusions, added LeBel J, would be in line with the concepts of comity and mutual respect between nations. ${ }^{24}$

The other immunity exception invoked by the appellant is found in section 6(a) of the Act: 'A foreign state is not immune from the jurisdiction of a court in any proceedings that relate to any death or personal injury.' He submitted that the mental distress, denial of liberty, and damage to reputation he suffered due to his wrongful arrest and imprisonment constituted a personal injury under this exception, resulting in Germany's sovereign immunity being set aside in his tort liability action. This argument was rejected by Justice LeBel following a rigorous interpretation of the provision at hand, including the complex bilingual and bijural ramifications of the legislation.

First, it was held that the common law distinction between acts of government (acta jure imperii) and acts of a commercial nature (acta jure gestionis), which operates to limit sovereign immunity with respect to the former and not the latter, has never been accepted in Canada ${ }^{25}$ and was certainly not incorporated in the statutory exception in section 6(a). In any event, this distinction would be irrelevant because, inter alia, the wording of the provision expressly provides that the exception applies to all wrongful

2111 ILM 470 (1972).

22 Report of the International Law Commission on the work of its forty-third session, UN Doc A/46/10, reproduced in Yearbook of the International Law Commission, vol 2 (New York: United Nations, 1991), part 2, at 13 (hereinafter Draft Articles).

23 Schreiber, at para. 17.

24 Ibid. at para. 27.

25 See Re Canada Labour Code [1992] 2 SCR 50; and, Government de la République démocratique du Congo v. Venne [1971] SCR 997. 
conducts by a foreign state which cause death or personal injury. Justice LeBel used parliamentary material to support this conclusion, namely the evidence presented by M. L. Jewell of the Constitutional and International Law Section, Department of Justice, before the Standing Senate Committee on Legal and Constitutional Affairs. ${ }^{26}$ This consultation confirms the trend at the Supreme Court of resorting to travaux préparatoires in statutory interpretation, even though the provision is not ambiguous (which was the old preliminary condition). ${ }^{27}$

Now, as LeBel J wrote, the main issue is whether 'the term "personal injury" in section 6(a) of the State Immunity Act applies only to claims of physical injury', ${ }^{28}$ or whether it applies 'to wrongful arrest and imprisonment' ${ }^{29}$ The appellant argued that there are conflicting judgments by the Court of Appeal for Ontario on the meaning of the provision at hand, ${ }^{30}$ and submitted that Canadian law has recognized that imprisonment, as well as the suffering of mental distress and damage to one's reputation, are injuries to the person, which should be included in the section 6(a) exception. The respondents countered that there was no personal injury within the meaning of the provision in this case.

The Court agreed with the respondents that the applicable case law in Anglo-Canadian common law, which is to the same effect as academic writings ${ }^{31}$ indicates that personal injury generally means physical injury. It is for the purpose of further supporting such interpretation of 'personal injury' in section 6(a) of the Act that Justice LeBel considered international law, including what was referred to as secondary sources of international law (the International Law Commission commentaries on its Draft Articles and the Council of Europe's Explanatory Reports on the European Convention on State Immunity and the Additional Protocol $)^{32}$ and the material submitted by Amnesty International on international human rights law.

For the discussion that follows, it is this passage of the reasons that is of particular interest, especially the remarks in response to the arguments founded upon international human rights law. Justice LeBel opined that Amnesty International's argument required a conclusion that there was a peremptory norm (otherwise known as ius cogens) 33 $^{33}$ of customary international

26 Senate of Canada, Proceedings of the Standing Senate Committee on Legal and Constitutional Affairs, Issue No 12, 19 April 1981, at p. 12:9.

27 See, generally, S. Beaulac, 'Recent Developments at the Supreme Court of Canada on the Use of Parliamentary Debates', 63 Saskatchewan L Rev 581 (2000); and, S. Beaulac, 'Parliamentary Debates in Statutory Interpretation: A Question of Admissibility or of Weight?', 43 McGill LJ 287 (1998).

28 Schreiber, at para. 38 .

29 Ibid.

30 United States of America v. Friedland (1999) 182 DLR (4th) 614 (Ont. CA); and, Walker v. Bank of New York Inc. (1994) 16 OR (3d) 504 (Ont. CA).

31 See K. D. Cooper-Stephenson and I. B. Saunders, Personal Injury Damages in Canada (Toronto: Carswell, 1981) at 5.

32 Strasbourg: Council of Europe, 1972.

33 The Vienna Convention on the Law of Treaties, UN Doc A/CONF 39/26, adopted 23 May 1969, entered into force 27 January 1980; reprinted in 8 ILM 679 (1969), and Can. TS 1980 No 37, 
law prevailing over the principle of sovereign immunity, that is, a norm calling for the extension of the concept of physical injury to include mental injury within the section 6(a) exception to sovereign immunity. In refusing to recognize such a norm, ${ }^{34}$ LeBel J expressed the following view:

In the case at bar, there is no conflict between the principles of international law, at the present stage of their development, and those of the domestic legal order. International law sets out some general principles with respect to the origins and uses of sovereign immunity, but the domestic law sets out very specific exceptions to the general rule of sovereign immunity. A judgment of this Court, Daniels v. White [1968] SCR 517, sets out when international law is appropriately used to interpret domestic legislation. In that case, Pigeon J held at p. 541 that:

... this is a case for the application of the rule of construction that Parliament is not presumed to legislate in breach of a treaty or in any manner inconsistent with the comity of nations and the established rules of international law. It is a rule that is not often applied, because if a statute is unambiguous, its provisions must be followed even if they are contrary to international law .... ${ }^{35}$

Justice LeBel held that 'there would be little utility in examining international legal principles in detail' ${ }^{36}$ because, here, there is no conflict between domestic law and international law given that the domestic legislation is more specific than the rule of international law, and because the issue is about the interpretation of the Act and not about international legal principles. ${ }^{37}$

This part of the decision is considered again later. ${ }^{38}$ Having clearly stated that the crux of the matter was the interpretation of the domestic law found in section 6(a) of the Act, LeBel J examined the term 'personal injury' in both the

defines a peremptory norm at article 53: 'For the purposes of the present Convention, a peremptory norm of general international law is a norm accepted and recognized by the international community of States as a whole as a norm from which no derogation is permitted and which can be modified only by a subsequent norm of general international law having the same character'; see also, concerning new rules of ius cogens, art 64 . The possible existence of such overriding principles of international law was alluded to by the majority of the International Court of Justice in the Barcelona Traction Case (Second Phase), ICJ Reports (1970) 3 , at 32. See also, on ius cogens, L. Hannikainen, Peremptory Norms (Jus Cogens) in International Law: Historical Development, Criteria, Present Status (Helsinki: Lakimiedliiten Kustannus, 1988).

34 Justice LeBel wrote, in Schreiber, at para. 49: 'Although I agree with some of the submissions of the intervener with respect to the fact that mental injury may be compensable in some form at international law, neither the intervener nor any other party has established that a peremptory norm of international law has now come into existence which would completely oust the doctrine of state immunity and allow domestic courts to entertain claims in the circumstances of this case' [emphasis added].

35 Schreiber, at para. 50 [emphasis added by LeBel J].

36 Schreiber, at para. 51.

37 Ibid.

38 Below $\mathrm{n}$ 116, and accompanying text. 
English and French versions of the provision, as well as the bijural ramifications of the federal legislation at issue. The latter involved taking into account the meaning of this expression in the Quebec civil law and considering the new English version of section 6(a), as amended by the Harmonization Act, ${ }^{39}$ which now reads: 'any death or personal or bodily injury'. ${ }^{40}$

In terms of statutory interpretation, generally, Justice LeBel referred to $R$. v. Sharpe $e^{41}$ to support the proposition that the proper way to construe legislation 'is to read its words in their entire context and in their grammatical and ordinary sense harmoniously with the scheme of the Act, the object of the Act and the intention of Parliament' ${ }^{42}$ This pronouncement is certainly borrowed from Driedger's Construction of Statutes, ${ }^{43}$ repeatedly quoted by the Supreme Court, ${ }^{44}$ which reads: 'Today there is only one principle or approach, namely, the words of an Act are to be read in their entire context and in their grammatical and ordinary sense harmoniously with the scheme of the Act, the object of the Act, and the intention of Parliament. ${ }^{45}$

Furthermore, since the two versions of federal statutes are equally authoritative, any ambiguity must be resolved by finding an interpretation common to both versions. Referring to Pierre-André Côté, The Interpretation of Legislation in Canada," Justice LeBel wrote that 'where one version is ambiguous and the other is clear and unequivocal, the common meaning of the two versions would a priori be preferred' and that 'where one of the two versions is broader than the other, the common meaning would favour the more restricted or limited meaning ${ }^{\prime}{ }^{47}$ Thus the French version of section 6(a) of the Act, which speaks of 'décès' or 'dommages corporels', should be favoured over the English version because it is clearer and more restrictive.

This interpretation, which refuses to include more than physical injury in the section 6(a) exception to sovereignty immunity, is also supported by a bijural consideration of the legislative context of the provision. The Quebec civil law uses the category of 'préjudice corporel-bodily injury' as part of the organizing classification of damages in the province's civil responsibility scheme, along with damages that are 'moral or material in nature'. This tripartite classification was set out clearly in article 1457 of the Civil Code of Quebec, ${ }^{48}$ but as LeBel J explained, the bodily injury category existed long

39 Federal Law-Civil Law Harmonization Act No. 1, SC 2001, c 4 (hereinafter Harmonization Act).

40 Ibid, at s 121.

41 [2001] 1 SCR 45.

42 Schreiber, at para. 54.

43 2nd edn (Toronto: Butterworths, 1983) at 87.

44 In recent years, to refer to just a few, see Bell ExpressVu Limited Partnership v. Rex, 2002 SCC 42, at para. 26 (hereinafter Bell ExpressVu); Francis v. Baker [1999] 3 SCR 250, at para. 34; and Rizzo $\mathcal{E}$ Rizzo Shoes Ltd. (Re) [1998] 1 SCR 27, at para. 21.

45 E. A. Driedger, above $\mathrm{n} 43$ at 87.

46 3rd edn (Montreal: Carswell, 2000) at 327.

47 Schreiber, at para. 56.

48 SQ 1991, c 64. 
before the adoption of the new code in $1991 .^{49}$ This civil law concept supports the conclusion according to which the ambit of section 6(a) of the Act is limited to injuries involving interference with the physical integrity of a person and does not include breach of rights of a moral nature.

Lastly, the Harmonization Act-which amendments are considered for the first time by the Court-does not command another meaning for section 6(a) of the Act. Justice LeBel noted that the redundancy created by the inclusion of 'bodily injury' with 'personal injury' was only intended to clarify the exception to sovereign immunity for the anglophone civil law audience. ${ }^{50}$ Once again, using parliamentary materials-this time, remarks by Anne McLellan, Minister of Justice and Attorney General of Canada when the bill was moved for the second reading ${ }^{51}$-it was held that the purpose of the amendment was not the creation of substantive rights. It follows also that the statutory interpretation principles about redundant drafting, especially the presumption against tautology, have no relevance here. ${ }^{52}$

\section{Discussion}

This paper seeks to examine whether the reasons given in Schreiber for brushing aside international human rights law and refusing to extend the scope of section 6(a) of the Act should be viewed as a change of heart by the Supreme Court with regard to the use of international law in interpreting statutes and other instruments like the Charter. The argument was that there exists a customary norm of international law, which would even be peremptory (i.e. a principle of ius cogens), commanding an interpretation of the Canadian legislation that included the protection of mental integrity through the exceptions to the general rule of sovereign immunity.

This issue must be considered in relation to the modern approach to international law in legislative interpretation and, in particular, the recent developments with the decisions in Baker, Hudson and Suresh.

49 Schreiber, at paras 60-65.

50 This is based also on the federal documents, prepared by the Department of Justice of Canada, entitled The Harmonization of Federal Legislation with the Civil Law of the Province of Quebec and Canadian Bijuralism, booklet 4, by L. M. Wellington, 'Bijuralism in Canada: Harmonization Methodology and Terminology' (Ottawa: Department of Justice, 2001) at 9-10; and, Bijural Terminology Records (Ottawa: Department of Justice, 2001) at 95.

51 Canada, House of Commons Debates, vol 137, 1st session, 37th Parliament, 7 May 2001, at 3640, where Minister McLellan said: 'Let me be clear that Bill S-4 does not create substantive rights or enshrine any new individual or collective rights'.

52 Schreiber, at paras 73-74. 


\subsection{International law and domestic statutory interpretation}

Generally, it is the judicial pronouncement by the Supreme Court in Daniels v. White $e^{53}$-referred to by LeBel J in Schreiber ${ }^{54}$ - which is deemed the starting point to any discussion on the principles of statutory interpretation when international law is involved in a case. However, one can trace back the restrictiveness of the Canadian approach to the British constitutional practice on the use of international norms. ${ }^{55}$ On behalf of the Judicial Committee of the Privy Council in Chung Chi Cheung v. The Queen, ${ }^{56}$ Lord Atkin explained the traditional rule thus:

The Courts acknowledge the existence of a body of rules which nations accept amongst themselves. On any judicial issue they seek to ascertain what the relevant rule is, and, having found it, they will treat it as incorporated into domestic law, so far as it is not inconsistent with rules enacted by statutes or finally determined by their tribunals. ${ }^{57}$

The problem with this statement is that it begs the question of when international law should be overridden by inconsistent statutes or case law.

However, since Daniels v. White ${ }^{58}$ in the late 1960 s, and especially with cases in the late 1980s onward, a change of approach in favour of a more liberal statutory interpretation can be identified at the Supreme Court, which increasingly resorted to international law to help construe domestic legislation. In 1988, La Forest J stated in R. v. Parisien ${ }^{59}$ 'In interpreting this undertaking, it must, as in the case of other terms in international agreements, be read in context and in light of its object and purpose as well as in light of the general principles of international law' ${ }^{60}$ In the 1990 case of National Corn Growers Assn. v. Canada (Import Tribunal), ${ }^{61}$ Gonthier J held: 'Indeed, where the text of the domestic law lends itself to it, one should also strive to expound an interpretation which is consonant with the relevant international obligations. ${ }^{62} \mathrm{He}$ further held:

The suggestion that recourse can be had to an underlying international agreement where a latent ambiguity can be asserted implies that there is

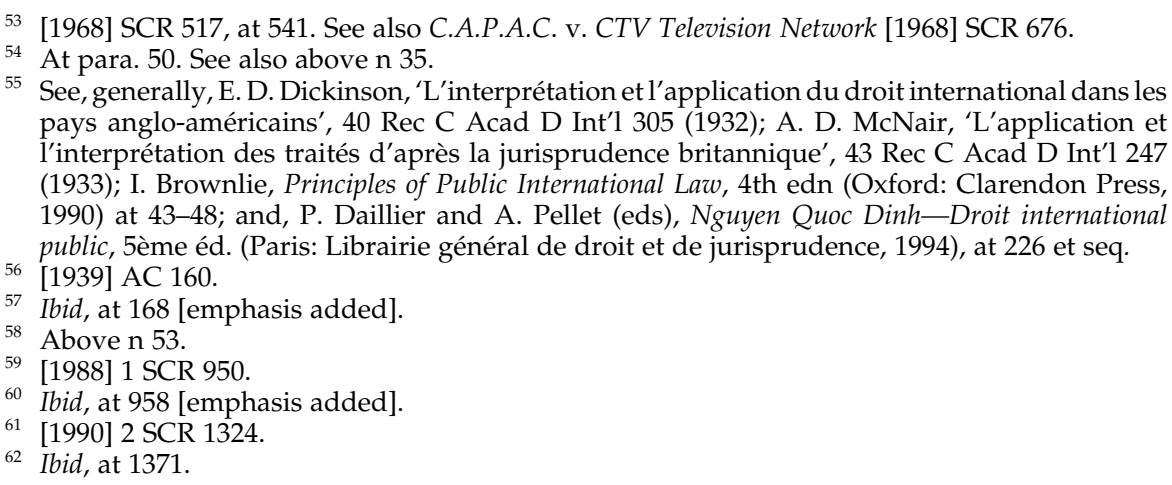
pays anglo-américains', 40 Rec C Acad D Int'l 305 (1932); A. D. McNair, 'L'application et l'interprétation des traités d'après la jurisprudence britannique', 43 Rec C Acad D Int'l 247 (1933); I. Brownlie, Principles of Public International Law, 4th edn (Oxford: Clarendon Press, 1990) at 43-48; and, P. Daillier and A. Pellet (eds), Nguyen Quoc Dinh-Droit international public, 5ème éd. (Paris: Librairie général de droit et de jurisprudence, 1994), at 226 et seq. 
no need to find a patent ambiguity before consultation of the agreement is possible. As a latent ambiguity must arise out of matters external to the text to be interpreted, such an international agreement may be used, as I have just suggested, as the preliminary stage of determining if an ambiguity exists. ${ }^{63}$

Accordingly, a treaty can be used in all circumstances, not only after the legislative provision at hand was held to be ambiguous. 'Although international law is not binding upon Parliamentary of the provincial legislatures,' as Justices Iacobucci and Major observed in Ordon Estate v. Grail,' 'a court must presume that legislation is intended to comply with Canada's obligations under international instruments and as a member of the international community. ${ }^{\prime 65}$

In Re Canada Labour Code, ${ }^{66}$ the Supreme Court applied the State Immunity Act - as in the Schreiber case - and granted only a limited sovereign immunity to state activities. For the majority, Justice La Forest observed that 'the proper approach to characterizing state activity is to view it in its entire context', ${ }^{67}$ which of course included its international law context. In Canada (Attorney General) v. Ward, ${ }^{68}$ again La Forest J made an extensive use of international legal sources in interpreting the refugee provisions of the Immigration Act, ${ }^{69}$ which incorporated the Convention Relating to the Status of Refugees ${ }^{70}$ into the Canadian legal order. The following year, in Thomson v. Thomson, ${ }^{71} \mathrm{La}$ Forest noted:

It would be odd if in construing an international treaty to which the legislature has attempted to give effect, the treaty were not interpreted in the manner in which the state parties to the treaty must have intended. Not surprisingly, then, the parties [to the case at bar] made frequent reference to this supplementary means of interpreting the Convention [on Child Abduction], and I shall also do so. ${ }^{72}$

Indeed, if there is one type of situation where international law undoubtedly ought to act as an aid to interpretation, it is when the enactment implements international treaty obligations.

More recently, in Pushpanathan v. Canada (Minister of Citizenship and Immigration $)^{73}$ it is Justice Bastarache who stated that there were obvious

63 Ibid, at 1372 [emphasis in original].

64 [1998] 3 SCR 437.

$65 \mathrm{Ibid}$, at 526.

66 [1992] 2 SCR 50.

67 Ibid, at 76.

68 [1993] 2 SCR 689.

69 RSC 1985, c I-2 (hereinafter Immigration Act).

70189 UNTS 150, signed 28 July 1951, entered into force 22 April 1954; reprinted in Can. TS 1969 No 6 (hereinafter Refugees Convention).

71 [1994] 3 SCR 551.

72 Ibid, at 578 .

73 [1998] 1 SCR 982. 
reasons why a court ought to resort to international law when asked to interpret implementing legislation:

Since the purpose of the [Immigration] Act incorporating Article IF(C) [of the Refugees Convention] is to implement the underlying Convention, the Court must adopt an interpretation consistent with Canada's obligations under the Convention. The wording of the Convention and the rules of treaty interpretation will therefore be applied to determine the meaning of Article $\operatorname{IF}(\mathrm{C})$ in domestic law. ${ }^{74}$

This in effect means that, along with international law used as an element of context to determine legislative intent, resort should also be had to international law's principles of interpretation, now codified in the Vienna Convention on the Law of Treaties, ${ }^{75}$ when considering such instruments.

To put this paradigm shift at the Supreme Court into perspective, the Charter should be credited at least in part for this change of approach which has led to the much more liberal consultation of international law. Indeed, since the adoption of the Charter in 1982, legal commentators have advocated recourse to international instruments to help in the construction of constitutionally protected rights and freedoms. ${ }^{76}$ The Supreme Court responded by adopting just such a method of interpreting the constitution-Reference Re Public Service Employee Relations Act, ${ }^{77}$ Slaight Communications Inc. v. Davidson $^{78}$ R. v. Keegstra, ${ }^{79}$ and again more recently in R. v. Burns. ${ }^{80}$ There can be

74 Ibid, at $1019-20$.

751155 UNTS 331, adopted 23 May 1969, entered into force 27 January 1980, reprinted in Can. TS 1980 No 37, at arts 31 and 32.

76 See S. J. Toope, 'Canada and International Law', 27 Canadian Council Int'1 L Proc 33 (1998); W. A. Schabas, International Human Rights Law and the Canadian Charter, 2nd edn (Scarborough, Can.: Carswell, 1996); A. F. Bayefsky, International Human Rights Law: Use in Canadian Charter of Rights and Freedoms Litigation (Toronto: Butterworths, 1992); M. Lebel, 'L'interprétation de la Charte canadienne des droits et libertés au regard du droit international des droits de la personne-Critique de la démarche suivie par la Cour suprême du Canada', 48 R du B 743 (1988); G. Zellick, 'The European Convention on Human Rights: Its Significance for Charter Litigation', in R. J. Sharpe (ed.), Charter Litigation (Toronto and Vancouver: Butterworths, 1987) at 97; M. A. Hayward, 'International Law and the Interpretation of the Canadian Charter of Rights and Freedoms: Uses and Justifications', 23 U Western Ont L Rev 9 (1985); T. Turp, 'Le recours en droit international aux fins de l'interprétation de la Charte canadienne des droits et libertés: un bilan jurisprudentiel', 18 R J Thémis 353 (1984); M. Cohen and A. F. Bayefsky, 'The Canadian Charter of Rights and Freedoms and Public International Law', 61 Canadian Bar Rev 265 (1983); J. Claydon, 'International Human Rights Law and the Interpretation of the Canadian Charter of Rights and Freedoms', 4 Supreme Court L Rev 287 (1982); E. P. Mendes, 'Interpreting the Canadian Charter of Rights and Freedoms: Applying International and European Jurisprudence on the Law and Practice of Fundamental Rights', 20 Alberta L Rev 383 (1982); and, G. Tremblay, 'La Charte canadienne des droits et libertés et quelques leçons de la Convention européenne des droits de l'homme', 23 C de D 795 (1982). See also, with regard to the Quebec provincial human rights legislation, M. Caron, 'L'utilisation du droit international aux fins d'interprétation et d'application de la Charte des droits et libertés de la personne du Québec', 1 Rev Québ D Int'1 307 (1984).

77 [1987] 1 SCR 313.

78 [1989] 1 SCR 1038.

79 [1990] 3 SCR 697.

80 [2001] 1 SCR 283. 
little doubt that opening the door to such use of international law for constitutional interpretation influenced the attitude for the construction of ordinary statutes.

\subsection{Recent developments at the Supreme Court of Canada}

The most recent developments at the Supreme Court of Canada in terms of the role of international law in statutory interpretation came out of the decisions in Baker, Hudson and Suresh. Now, before evaluating whether the Schreiber case constitutes a break in the modern approach just identified, a brief examination of the latest judgments that exemplify this trend is certainly in order.

\subsubsection{The Baker case}

In this case, the Supreme Court had to decide whether or not an order to deport a woman with Canadian-born dependent children should be reviewed. The appellant had applied for an exemption based on humanitarian and compassionate considerations under section 114(2) of the Immigration Act. The scope of 'humanitarian and compassionate consideration' was ascertained by the majority, per Justice L'Heureux-Dubé, ${ }^{81}$ having regard to the Minister's guidelines and also in light of international law. Because the interests of children, protected in the Convention on the Rights of the Child, ${ }^{82}$ fall within humanitarian and compassionate reasons not to deport, this international instrument was considered as an element of legislative context.

This convention was ratified by Canada but has yet to be implemented into the domestic legal order which, according to the traditional position, ${ }^{83}$ meant that the norms contained therein could not directly apply to the case at hand. It is here that Justice L'Heureux-Dubé made the following groundbreaking remarks:

I agree with the respondent and the Court of Appeal that the Convention has not been implemented by Parliament. Its provisions therefore have no direct application within Canadian law. Nevertheless, the values reflected in international human rights law may help inform the contextual approach to statutory interpretation and judicial review. ${ }^{84}$

81 Justices Cory and Iacobucci wrote a set of concurring reasons, actually pointing out their disagreement in using unimplemented treaty obligations in interpreting Canadian domestic legislation.

82 GA Res 44/25, 44 UN GAOR, Supp (No 49), UN Doc A/44/49 at 166 (1989), adopted 20 November 1989, entered into force 2 September 1990; reprinted in 28 ILM 1448 (1989) and Can. TS 1992 No 3 (hereinafter Convention on the Rights of the Child).

83 Justice L'Heureux-Dubé referred to Francis v. Queen [1956] SCR 618 at 621; and, Capital Cities Communications Inc. v. Canadian Radio-Television Commission [1978] 2 SCR 141 at 172-73.

84 Baker, at para. 69-70 [emphasis added]. 
A reference to Driedger on the Construction of Statutes ${ }^{85}$ followed, explaining that international law (both treaties and custom) forms part of the legal context in which legislative interpretation is conducted. Other common law countries, it was also observed, have recognized the role of international human rights in construing domestic law. ${ }^{86}$

Accordingly, the majority felt justified to take into account the values and principles of the Convention on the Rights of the Child, more particularly those concerning the best interests of children and how they should be considered when making decisions relating to and affecting their future. ${ }^{87}$ Other international instruments providing protection for children and childhood were considered by L'Heureux-Dubé J, including the 1948 Universal Declaration of Human Rights ${ }^{88}$ and the 1959 Declaration of the Rights of the Child. ${ }^{89}$ Such international rules were thus used as part of the legislative context for the interpretation of section 114(2) of the Immigration Act and helped decide that the Minister's power had been exercised unreasonably.

\subsubsection{The Hudson case}

In Hudson, reference was made to Baker, and international law was also resorted to as an aid to the interpretation of the domestic legislation at issue. Unlike Baker, however, there was no unimplemented treaty obligation. Here, the appellants were companies providing landscaping and lawn care services, in the course of which they used pesticides approved by the Federal Pest Control Products Act; ${ }^{90}$ they had also obtained the requisite licences under the Pesticides Act, ${ }^{91}$ a Quebec statute. The city of Hudson, the respondent, charged the appellants with pesticides use in violation of municipal by-law no. 270, which was adopted pursuant to the enabling legislation. The appellants argued that this by-law was ultra vires of the town's authority.

The statutory interpretation question concerned the extent of legislative authority enjoyed by the respondent to regulate the use of pesticides on its territory, which was provided for in the Cities and Towns Act. ${ }^{92}$ Justice

${ }^{85}$ R. Sullivan, Driedger on the Construction of Statutes, 3rd edn (Toronto: Butterworths, 1994) at 330.

86 Justice L'Heureux-Dubé referred to the decision of the New Zealand Court of Appeal in Tavita v. Minister of Immigration [1994] 2 NZLR 257 at 266; and to a judgment by the Supreme Court of India, Vishaka v. Rajasthan [1997] 3 LRC 361 at 367.

87 Baker, at para. 71 .

88 GA Res 217A (III), UN Doc A/810, 71 (1948), adopted 10 December 1948, in its preamble.

${ }^{89}$ GA Res 1386 (XIV), 14 UN GAOR, Supp (No 16), UN Doc A/4354, 19, adopted 20 November 1959 ; in its preamble.

90 RSC 1985, c P-9.

91 RSQ, c P-9.3.

92 RSQ, c C-19, as ammended (hereinafter Cities and Towns Act). 
L'Heureux-Dubé, for the majority, ${ }^{93}$ recalled her reasons in Baker and referred again to Driedger on the Construction of Statutes, ${ }^{94}$ this time to support the proposition that both treaties and customary international law should inform the contextual interpretation of domestic statutes. It is the so-called precautionary principle at international law that was used in this case to confirm the conclusion according to which section 410(1) of the Cities and Towns Act and by-law 270 allow the respondent to regulate pesticide use on its territory. ${ }^{95}$

The Bergen Ministerial Declaration on Sustainable Developments ${ }^{96}$ gave a definition to the precautionary principle and L'Heureux-Dubé J observed that it was now 'codified in several items of domestic legislation' ${ }^{97}$ - the Oceans Act, ${ }^{98}$ the Canadian Environmental Protection Act 1999, ${ }^{99}$ and Nova Scotia's Endangered Species Act. ${ }^{100}$ In terms of sources of international law, however, the nature of the principle at hand remained unclear. ${ }^{101}$ Justice L'Heureux-Dubé made no reference to treaty provisions (implemented or not), which seems to indicate that the rule she was alluding to was customary. ${ }^{102}$ In any event, be it customary or conventional, and irrespective of whether or not the latter is incorporated into the domestic legal order, international law was deemed relevant in deciding that the Cities and Towns Act authorized the regulation of pesticide use.

93 Justices Iacobucci, Major and LeBel wrote a set of concurring reasons.

94 Above $\mathrm{n} 85$ at 330 .

95 On this, see the recent literature by D. VanderZwaag, 'The Precautionary Principle in Environmental Law and Policy: Elusive Rhetoric and First Embraces', 8 J Environmental L \& Pol 355 (1998); T. O'Riordan, J. Cameron and A. Jordan (eds), Reinterpreting the Precautionary Principle (London: Cameron May, 2001); and A. Trouwborst, Evolution and Status of the Precautionary Principle in International Law (The Hague and Boston: Kluwer Law International, 2002).

96 A/CONF 151/PC/10,6 August 1990, at para. 7: 'In order to achieve sustainable development, policies must be based on the precautionary principle. Environmental measures must anticipate, prevent and attack the causes of environmental degradation. Where there are threats of serious or irreversible damage, lack of full scientific certainty should not be used as a reason for postponing measures to prevent environmental degradation.'

97 Hudson, at para. 31.

98 SC 1996, c 31, at para. 6 of the preamble.

99 SC 1999, c 33, at s 2(1)(a).

100 SNS 1998, c 11, at ss 2(1)(h) and 11(1).

101 The sources of international law are generally regarded as being those provided for in art 38(1) of the Statute of the International Court of Justice, 1 UNTS xvi, which reads: 'The Court, whose function is to decide in accordance with international law such disputes as are submitted to it, shall apply: (a) international conventions, whether general or particular, establishing rules expressly recognized by the contesting States; (b) international custom, as evidence of a general practice accepted as law; (c) the general principles of law recognized by civilized nations; (d) subject to the provisions of Article 59, judicial decisions and the teachings of the most highly qualified publicists of the various nations, as subsidiary means for the determination of rules of law.'

102 See Hudson, at para. 32. 


\subsubsection{The Suresh case}

In Suresh, the Supreme Court was asked to review the Minister of Immigration's decision to deport the appellant, who had been recognized as a refugee under the Refugees Convention. The Immigration Act-which, inter alia, incorporates international norms on refugees into Canadian law-states that there must be no refoulement 'to a country where a person's life or freedom would be threatened for reasons of race, religion, nationality, membership in a particular social group or political group or political opinion'. ${ }^{103}$ However, there is an exception under the Immigration Act authorizing such deportation for reasons of national security, which was the basis for the order to deport the appellant who was suspected of terrorist activities. The invoked grounds for judicial review included procedural unfairness and Charter right infringements.

In order to determine whether the Immigration Act, s 53(1)(b), which allows deportation 'to a country where the person's life or freedom would be threatened', infringes the constitutional principles of fundamental justice in article 7 of the Charter, the situation at international law was examined by 'the Court'. ${ }^{104}$ Similar to the majority in Baker (to which, however, there was no reference here), unimplemented treaty norms were held to be useful for interpretation purposes:

International treaty norms are not, strictly speaking, binding in Canada unless they have been incorporated into Canadian law by enactment. However, in seeking the meaning of the Canadian Constitution, the Court may be informed by international law. Our concern is not with Canada's international obligation qua obligations; rather, our concern is with the principles of fundamental justice. We look to international law as evidence of these principles and not as controlling in itself. ${ }^{105}$

Unlike Baker, however, where such norms were used by the majority to ascertain the meaning of domestic legislation (section 114(1) Immigration Act), here, it was to construe a constitutional right enshrined in the Charter (the principles of fundamental justice in section 7) that the Court made reference to international law.

From an international perspective, the prohibition on torture was first held to be a rule of ius cogens. This was evidenced by (i) the large number of multilateral instruments prohibiting torture, ${ }^{106}$ (ii) the domestic state practice

\footnotetext{
${ }^{103}$ Immigration Act, s 53(1).

104 'A complete understanding of the [Immigration Act] and the Charter requires consideration of the international perspective; Suresh at para. 59.

105 Suresh, at para. 60 [emphasis added].

106 The Court referred to the Geneva Convention Relative to the Treatment of Prisoners of War, 75 UNTS 135, adopted 12 August 1949, entered into force 21 October 1950; reprinted in Can. TS 1965 No 20, 84; at art 3; the Geneva Convention for the Amelioration of the Condition of the Wounded and Sick in Armed Forces in the Field, 75 UNTS 31, adopted 12 August 1949,
} 
against torture in the administration of justice, ${ }^{107}$ and (iii) the doctrinal works ${ }^{108}$ and case law ${ }^{109}$ showing prohibition on torture as such a peremptory norm. ${ }^{110}$ Then, the Court referred to regular conventional international law-articles 4 and 7 of the International Covenant on Civil and Political Rights (ICCPR) $)^{111}$ (interpreted in light of General Comment No 20) ${ }^{112}$ as well as articles 1, 2, 3, and 16 of the Convention against Torture and other Cruel, Inhuman or Degrading Treatment or Punishment (CAT). ${ }^{113}$ Ratified but untransformed into Canadian law, these treaties were relied upon to support the conclusion that 'a state is not to expel a person to face torture, which includes both the physical and mental infliction of pain and suffering, elsewhere'. ${ }^{114}$

This general prohibition at international law, however, appears to be qualified by another treaty which, unlike the previous two, Canada has both ratified and incorporated into its legal system, namely the Refugee Conven-

entered into force 21 October 1950; reprinted in Can. TS 1965 No 20, 25; at art 3; the Geneva Convention for the Amelioration of the Condition of the Wounded, Sick and Shipwrecked Members of Armed Forces at Sea, 75 UNTS 85, adopted 12 August 1949, entered into force 21 October 1950; reprinted in Can. TS 1965 No 20, 55; at art 3; the Geneva Convention Relative to the Protection of Civilian Persons in Time of War, 75 UNTS 287, adopted 12 August 1948, entered into force 21 October 1950; reprinted in Can. TS 1965 No 20, 163; at art 3; the Universal Declaration of Human Rights above n 88; at art 5; the Declaration on the Protection of All Persons from Being Subjected to Torture and Other Cruel, Inhuman or Degrading Treatment or Punishment, GA Res 3452 (XXX), UN Doc A/10034, 91 (1976), adopted 9 December 1975; the International Covenant on Civil and Political Rights, see above $n$ 85; at art 7; the European Convention for the Protection of Human Rights and Fundamental Freedoms, 213 UNTS 221, ERS 5.41, signed 4 November 1950, entered into force 3 September 1953; at art 3; the American Convention on Human Rights, OASTS 36, signed 22 November 1969, entered into force 18 July 1978; OAS Off. Rec. OEA/Ser.L/V/11.23, doc 21, rev.6 (1979); reprinted in 9 ILM 673 (1970); at art 5; the African Charter on Human and Peoples' Rights, OAU Doc CAB/LEG/67/3, adopted 27 June 1981, entered into force 21 October 1986; reprinted in 21 ILM 58 (1981), and 7 HRLJ 403; at art 5; the Universal Islamic Declaration of Human Rights, 9 The Muslim World League Journal 25 (1981), at article VII.

107 Suresh, at para. 63.

${ }^{108}$ Reference was made to L. Hannikainen, above n 33, at 509, and M. N. Shaw, International Law, 4th edn (Cambridge: Cambridge University Press, 1997) at 203-04.

${ }^{109}$ See Prosecutor v. Furundzija (1998) 38 ILM 317 (1999) (International Criminal Tribunal for the Former Yugoslavia, Trial Chamber); and, R. v. Bow Street Metropolitan Stipendiary Magistrate et al., Ex p. Pinochet Ugarte (No 3) [1999] 2 WLR. 827 (House of Lords).

110 Suresh, at para. 64.

${ }^{111}$ GA Res 2200A (XXI), UN Doc A/6316 (1966), 999 UNTS 171, adopted 16 December 1966, entered into force 23 March 1976; reprinted in 6 ILM 368 (1967), and Can. TS 1976 No 47 (hereinafter ICCPR).

112 United Nations, Human Rights Committee, General Comment 20, Article 7 (Forty-fourth session, 1992), Compilation of General Comments and General Recommendations Adopted by Human Rights Treaty Bodies, UN Doc HRI/Gen/1/Rev.1, 30 (1994), reads: 'States parties must not expose individuals to the danger of torture [...] upon return to another country by way of their extradition, expulsion, or refoulement.'

${ }^{113}$ GA Res 39/46, 39 UN GAOR, Supp (No 51), UN Doc A/39/51, 197 (1984), reprinted in 23 ILM 1027 (1984), minor changes reprinted in 24 ILM 535 (1985), 5 HRLJ. 350 (1984) and Can. TS 1987 No 36 (hereinafter CAT).

114 Suresh, at para. 68. 
tion. After establishing a similar prohibition of refoulement, article 33(2) of this treaty provides: 'The benefit of the present provision may not, however, be claimed by a refugee whom there are reasonable grounds for regarding as a danger to the security of the country.' But the Court rejected the argument that the anti-deportation provisions in the ICCPR and the CAT could be derogated from because of the Refugee Convention, holding that the former instruments expressed a 'prevailing international norm' ${ }^{115}$ Based in part on this international perspective, the Court concluded that the refoulement of a person who is likely to face torture, save in the most extraordinary circumstances, constitutes an unjustifiable infringement of the Charter. ${ }^{116}$ In the end, the appellant was entitled to a new deportation hearing.

\section{Conclusion}

Now, where does Schreiber fit in this trend welcoming recourse to international law in interpreting domestic statutes? There is little doubt that, intentionally or not, a very different tone emerged from these reasons, which spoke of some formal requirement of finding a conflict ${ }^{117}$ between the domestic legislative provision and the international legal norm invoked before the latter can act as an aid to interpretation. With all due respect to Justice LeBel, who is certainly one of the liberal interpreters on the bench, it is difficult to read the relevant passages otherwise than as clashing with contemporary case law on the issue.

Indeed, it was held in Schreiber that the 'questions at stake fall within the purview of the domestic legislation',' ${ }^{118}$ and that 'the case turns on the interpretation of the bilingual versions of section 6(a) of State Immunity Act, discussed [above], rather than the interpretation of international law principles ${ }^{\prime 119}$ This attitude greatly contrasts with the discourse recently expressed by the Court, most forcefully in Baker, suggesting the unimpeded consideration of international legal norms 'to help inform the contextual approach to statutory interpretation'. ${ }^{120}$ The latter approach calls for the reconciliation of domestic and international norms through interpretation, while that adopted in Schreiber seems to favour a compartmented, even perhaps confrontational,

115 Suresh, at para. 72. The Court, in order to support the conclusion that the CAT enjoys a dominant status in international law referred to, inter alia, United Nations, Committee Against Torture, Conclusions and Recommendations of the Committee against Torture: Canada, UN Doc CAT/C/XXV/Concl. 4 (2000).

${ }^{116}$ Suresh, at paras 76-79.

117 Justice LeBel wrote, in Schreiber, at para. 50: 'In the case at bar, there is no conflict between the principles of international law, at the present stage of their development, and those of the domestic legal order. International law sets out some general principles with respect to the origins and uses of sovereign immunity, but the domestic law sets out very specific exceptions to the general rule of sovereign immunity' [emphasis added].

118 Schreiber, at para. 51.

119 Schreiber, at para. 51 [emphasis added].

${ }^{120}$ Baker, at para. 70 . 
view of the two orders. Further, such reluctance to use international law is all the more surprising given that the State Immunity Act is an implementing statute, that is, the type most appropriately involving reference to such norms in ascertaining legislative intent, according to the Court. ${ }^{121}$

More troublesome is LeBel J's reference to Daniels v. White ${ }^{122}$ as the authority on the use of international law in statutory interpretation. In that case, Pigeon J wrote that 'if a statute is unambiguous, its provisions must be followed even if they are contrary to international law' ${ }^{\prime 23}$ This excerpt unearths the Chung Chi Cheung ${ }^{124}$ terminology and suggests that international law will prevail over-not reconcile with-Canadian law when the domestic statute is clear, that is, when there is no ambiguity on the meaning of the legislative provision. The fundamental problem which arises with such a test, many times highlighted by general commentators on statutory interpretation, ${ }^{125}$ is to decide whether the legislation is ambiguous or unambiguous. As Lord Oliver of Aylmerton noted in Pepper v. Hart: ${ }^{126}$ 'Ingenuity can sometimes suggest ambiguity or obscurity where none exists in fact. ${ }^{\prime 27}$

Furthermore, this 'ambiguity requirement ${ }^{\prime 28}$ constitutes a manifestation of the rhetoric of the literal rule of statutory interpretation, otherwise known as the plain meaning rule. ${ }^{129}$ This restrictive approach to legislation was born in Great Britain at a time when courts considered that 'Parliament generally changes the law for the worse ${ }^{130}$ and that a statute was an 'alien intruder in the house of the common law'. ${ }^{131}$ The plain meaning rule has long been criticized by courts and commentators, and it now appears to be rejected in

${ }^{121}$ See Re Canada Labour Code, above n 66; Canada (Attorney General) v. Ward, above n 68; Thomson v. Thomson, above n 71; and, Pushpanathan v. Canada (Minister of Citizenship and Immigration), above $\mathrm{n} 73$.

122 Above $n 53$.

${ }^{123}$ Ibid, at 541 [emphasis added].

${ }^{124}$ Above $\mathrm{n} 56$ and accompanying text.

${ }^{125}$ See, for instance, C. B. Nutting, 'The Ambiguity of Unambiguous Statutes', 24 Minnesota L Rev 509 (1940).

126 [1993] AC 593 (HL).

127 Ibid, at 620 .

${ }^{128}$ On the different types of ambiguous, obscure or unclear legislation, see T. St J.N. Bates, 'The Contemporary Use of Legislative History in the United Kingdom', 54 Cambridge L J 127, at 139-45 (1995).

${ }^{129}$ See R. Sullivan, above n 85, at 430; and, J. M. Kernochan, 'Statutory Interpretation: An Outline of Method', 3 Dalhousie L J 333, at 343-44 (1976).

${ }^{130}$ F. Pollock, Essays in Jurisprudence and Ethics (London: Macmillan, 1882) at 85.

${ }^{131}$ H. F. Stone, 'The Common Law in the United States', 50 Harvard L Rev 4, at 15 (1936). 
most common law jurisdictions. ${ }^{132}$ In Pepper v. Hart, ${ }^{133}$ Lord Griffiths appositely observed:

The days have long passed when the courts adopted a strict constructionist view of interpretation which required them to adopt the literal meaning of the language. The courts now adopt a purposive approach which seeks to give effect to the true purpose of legislation and are prepared to look at much extraneous material that bears upon the background against which the legislation was enacted. ${ }^{134}$

As Justice L'Heureux-Dubé wrote, dissenting in 2747-3174 Québec Inc. v. Quebec (Régie des permis d'alcool): ${ }^{135}$ 'In reality, the "plain meaning" can be nothing but the result of an implicit process of legal interpretation'. ${ }^{136}$

The legislative intent now predominantly tends to be ascertained with reference to a much broader perspective, through a modern approach that the commentator Francis Bennion calls the 'informed interpretation' ${ }^{137}$ Pursuant to this method, when one is asked to construe a statute, one ought to put the emphasis not only on the language used, but also equally on the purpose and context of the enactment. ${ }^{138}$ This is the approach that Justice L'Heureux-Dubé began to advocate in Hills v. Canada (Attorney General) ${ }^{139}$ in 1988, and which seems to have become dominant at the Supreme Court during the 1990s, with judgments like Verdun v. Toronto-Dominion Bank, ${ }^{140}$ Royal Bank of Canada v. Sparrow Electric Corp. ${ }^{141}$ Rizzo \& Rizzo Shoes Ltd. ${ }^{142}$ R. v. Gladue, ${ }^{143}$ and again in the 2002 case of Bell ExpressVu.

Accordingly, it is with some concerns that the author is forced to conclude that Schreiber indeed seems to signal a change of heart by the Supreme Court

${ }^{132}$ See, for example, the following authors: N. J. Singer, Statutes and Statutory Construction, vol 2A, 5th edn (New York: Clark Boardman Callaghan, 1992) at 2-3; and, M. Zander, The Law-Making Process, 4th edn (London: Butterworths, 1994), at 121-27. As far as the judiciary is concerned, in England, see Lord Denning's speech in Magor and St. Mellons Rural District Council v. Newport Corporation [1950] 2 All ER 1226, at 1236 (CA): 'We sit here to find out the intention of Parliament and of Ministers and carry it out, and we do this better by filling in the gaps and making sense of the enactment than by opening it up to destructive analysis. In the United States of America, see Holmes J's comments in Towne v. Eisner, 245 US 372, at 376 (1917): 'A word is not a crystal, transparent and unchanged, it is the skin of a living thought;' see also Learned Justice Hand, in Giuseppi v. Walling, 144 F2d 608, at 624 (2nd Cir 1944), who wrote: 'There is no surer way to misread any document than to read it literally.'

133 Above $\mathrm{n} 121$.

${ }^{134}$ Ibid, at 617.

135 [1996] 3 SCR 919.

136 Ibid, at para. 154 [emphasis in original].

${ }^{137}$ F. A. R. Bennion, Statutory Interpretation: A Code, 2nd edn (London: Butterworths, 1992), at 427-29. What is referred to as the 'informed interpretation' is called the 'modern interpretation rule' by R. Sullivan (above n 85, at 131-35) and 'pragmatic dynamism' by W. N. Eskridge (Dynamic Statutory Interpretation (Cambridge, U.S.: Harvard University Press, 1994), at 50-57).

138 See P.-A. Côté, Interprétation des lois, 3rd edn (Montreal: Thémis, 1999), at 364-73.

${ }^{139}$ [1988] 1 SCR 513.

140 [1996] 3 SCR 550.

141 [1997] 1 SCR 411.

142 Above $\mathrm{n} 42$.

${ }^{143}$ [1999] 1 SCR 688. 
of Canada with regard to the use of international law in domestic statutory interpretation. More alarming would be to think of the reference made to Daniels v. White, ${ }^{144}$ and the misleading discourse on 'ambiguity,' as a step backward in favour of the plain meaning rule of construction, which semiotic effect on the shared consciousness of the legal community, including that of our magistrates, continues in spite of the relentless efforts of some members of our highest court to rid us of this mythical reality. ${ }^{145}$

${ }^{144}$ Above $\mathrm{n} 51$.

${ }^{145}$ On the creation and transformation of human constructed reality through the use of language and myth, see L. Wittgenstein, Tractatus Logico-Philosophicus (London: Routledge and Kegan Paul, 1961); and, L. Wittgenstein, Philosophical Investigations (Oxford: Basil Blackwell, 1958); as well as C. K. Ogden and I.A. Richards, The Meaning of Meaning-A Study of the Influence of Language upon Thought and of the Science of Symbolism, 2nd edn (London: Kegan Paul, 1927). 